\title{
Türk-Yunan Mübadelesinde Hilâl-i Ahmer Cemiyeti 27. İmdad-ı Sıhhî Heyeti'nin Selanik'teki Faaliyetleri (Ekim 1923-Ekim 1924)
}

Hüseyin Çavdar ${ }^{1}$

\section{Öz}

Lozan görüşmelerinde kabul edilen Türk-Yunan ahalisinin mübadelesi sözleşmesi 25 Ağustos 1923 tarihinde TBMM tarafından yürürlüğe konuldu. Bu sözleşmeye göre İstanbul'da yaşayan Ortodoks Rumlar ile Batı Trakya'da yaşayan Müslüman Türkler sözleşmenin dışında tutulmuş ve geri kalan ahalinin mübadelesine 1 Mayıs 1923'ten itibaren başlanılması kararlaştırılmıştır. Sözleşmenin yürürlüğe girmesinden sonra mübadele işleri ile alakadar olması için Eylül 1923'te Mübadele İmar ve İskân Vekâleti kurulmuştur. Vekâlet'in bütçesi ve teşkilatlanma biçimi mübadele işlerini tek başına gerçekleştirmesini mümkün kılmamıştı. Bundan dolayı Vekâlet Eylül 1923 tarihinden itibaren Hilâl-i Ahmer Cemiyeti ile görüşmelere başlamış ve Hilâl-i Ahmer Cemiyeti de mübadele işlerine dâhil edilmiştir. Cemiyet tarafından gerek Türkiye'de gerekse Yunanistan'da imdad heyetleri teşkil edilmiş ve bu imdad heyetleri vasıtasıyla Türkiye'ye sevk edilecek olan mübadillerin ihtiyaçları ile ilgilenilmiştir. Cemiyetin kurmuş olduğu imdad heyetlerinden biri de 27. Selanik Imdad Heyeti'dir. Bu heyet, mübadele boyunca yüz binlerce kişinin sağlık, iaşe, iskân ve diğer sorunlarıyla ilgilenmiştir.

Bu makalede Kızılay Arşivi, Hilâl-i Ahmer Mecmuası, TBMM Zabıt Cerideleri, Hilâl-i Ahmer Cemiyeti tarafından hazırlanan raporlar ve araştırma eserler incelenerek, mübadelede Hilâl-i Ahmer Cemiyeti 27. İmdad-ı Sıhhî Heyeti'nin Selanik'teki faaliyetleri incelenmiştir.

Anahtar Kelimeler: Hilâl-i Ahmer, Selanik, Mübadele, 27. İmdad-ı Sıhhî Heyeti.

\section{The Activities of Turkish Red Crescent Association of the 27th Salonika Help Committee in Population Exchange (October 1923-October 1924)}

\section{Abstract}

The Turkish- Greek Population Exchange Agreement which has accepted between Turkey and Greece in the Conference of Lousanne, was brought into force by Turkish Grand National Assembly on 25 August 1923. As agreed upon

\footnotetext{
${ }^{1}$ Yüksek Lisans Öğrencisi, Sakarya Üniversitesi Sosyal Bilimler Enstitüsü, Tarih Bölümü, Türkiye Cumhuriyeti Ana Bilim Dalı, semihcavdar.20@hotmail.com. (Makale Gönderim Tarihi: 07.03.2018; Makale Kabul Tarihi: 02.04.2018) (ORCID ID: 0000-0002-9041-9053).
}

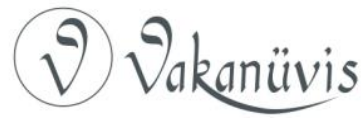


Greek Orthodox Christians living in Istanbul and Turkish Muslims living in Western Thrace were excluded and all the other community was started to be exchanged starting from the date 1 May 1923. After agreement brought into force, Exchange, Construction and Settlement Ministry was founded to be concerned with the issues regarding the Exchange. However, the budget and the organization of the ministry were not enough to accomplish all the works about exchange itself. Fort he reason, the Ministry started negatiations with Turkish Red Crescent Association and two worked together on exchange issues. Both in Turkey and Greek committees of help were founded by Turkish Red Crescent Association. These committees dealt with needs of people who were exchanged. One of the committees founded by Turkish Red Crescent Association was the 27th Salonika Help Committee. This Committee helped hundreds of thousands people in terms of health, food housing and other problems.

This article aims at analizing the activities of 27th Help Committee in Salonika in terms of Red Crescent Archive, Ottoman Red Crescent Journals, Turkish Grand National Assembly Official Reports and the reports ve research works prepared by Turkish Red Crescent Association.

Keywords: Red Crescent Association, Selanik, Exchange, 27th Salonika Committee

\section{Giriş}

Günümüzde Kızılay olarak bilinen Hilâl-i Ahmer Cemiyeti, Osmanlı'dan günümüze miras kalan önemli kuruluşlardan bir tanesidir. Hilâl-i Ahmer Cemiyeti, Salib-i Ahmer yani Kızılhaç olarak tanınan insani yardım teşkilatının İslam dünyasındaki adıdır. Kızılhaç örgütünün fikir babası İsviçre vatandaşı olan Henry Dunant'tır. Dunant, savaş meydanlarında yaralılara yardım edecek ve tarafsız sayılacak bir örgütün kurulması için tüm insanlara çağrıda bulunmuştu². Avrupalı ülkeler Dunant'ın bu çağrısına kayıtsız kalmamış ve 1863 yılında Cenevre'de toplanarak Kızılhaç örgütünün temellerini atmışlardır ${ }^{3}$.

Avrupalı devletlerin büyük ilgi göstermeye başladığı Kızılhaç fikri, Osmanlı Devleti'nin de dikkatini çekmiştir. 5 Temmuz 1865 yılında

${ }^{2}$ Seçil Karal Akgün, Murat Uluğtekin, Hilâl-i Ahmer'den Kızılay'a, TDV Yayıncılık, Ankara, 2002, s.8-9.

${ }^{3}$ Türk Kızılay'ı 2010-2015 Stratejik Planı, s. 10

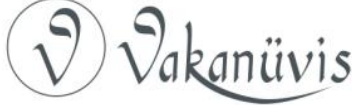


Osmanlı Devleti'nin de imzaladığı ${ }^{4}$ Cenevre sözleşmesinin tatbiki için Miralay Abdullah Bey ve Marko Paşa görevlendirilmiştir. İilinin çabaları ile 11 Haziran 1868 tarihinde Mecrûhîn ve Marzâ-yi Askeriyyeye İmdad ve Muâvenet Cemiyeti (Yaralı ve Hasta Askerlere Yardım Cemiyeti) adı altında Hilâl-i Ahmer'in temelleri atılmıştır. ${ }^{5}$

Kuruluşunun ilk yıllarında etkin olamayan cemiyet, II. Abdülhamid tahta çıktıktan sonra 14 Nisan 1877 tarihinde Osmanlı Hilâl-i Ahmer Cemiyeti adı altında yeniden kuruldu ${ }^{6}$. 1877-78 Osmanlı-Rus ve 1897 yılında meydana gelen Türk-Yunan muhaberelerinde önemli hizmetler görmesine rağmen ${ }^{7}$, genel olarak II. Abdülhamid dönemi boyunca atıl kalmıştır. Cemiyet, II. Meşrutiyet'ten sonra 20 Nisan 1911 tarihinde Tokatlıyan Oteli'nde Sadrazam Hakkı Paşa başkanlığında 100 kurucu üyenin katılımı ile yeniden ihya edildi. Sultan Reşad'ın himayesine aldığı cemiyetin fahri başkanı Şehzade Yusuf izzettin Efendi oldu. Şehzade Yusuf İzzetin Efendi cemiyetin faaliyetlerine önem vermiş ve Tophane'de kendisine ait olan bir binayı Cemiyet'e bağışlamıştır ${ }^{8}$. Cemiyet, yeniden teşkil edildikten sonra Trablusgarp ve Balkan Savaşları'nda önemli hizmetleri yerine getirdi'.

I. Dünya Savaşı ve Milli Mücadele'de de yararlılıkları görülen Hilâl-i Ahmer Cemiyeti'ni çok önemli bir görev daha beklemekteydi. TürkYunan Mübadelesini İmar ve İskân Vekâleti ile birlikte yürütmek.

Sözlük anlamı değiş-tokuş olan mübadele teriminin göç kapsamındaki anlamını ise iki ülke arasında karşılıklı anlaşma sonucu

${ }^{4}$ Mustafa Sarı, “Milli Mücadele Dönemi’nde İzmit ve Çevresinde Hilâl-i Ahmer Cemiyeti'nin Faaliyetleri (1919-1923)", Uluslararası Gazi Akça Koca ve Kocaeli Tarihi Sempozyumu Bildirileri, C. II, Kocaeli Büyükşehir Belediyesi Yayınları, Kocaeli, 2015, s. 966.

${ }^{5}$ Mesut Çapa, "Kızılay", İslam Ansiklopedisi, C. XXV, 2002, s.545.

${ }^{6}$ Osmanlı Hilâl-i Ahmer Cemiyeti Salnamesi (1329-1331), Matbaa-i Ahmet ihsan ve Şükerâsı, İstanbul, (t.y.), s. 27-29.

7 Milli Mücadele de Hilâl-i Ahmer (Türkiye Büyük Millet Meclisi'nin Teşkilinden Sakarya Zaferine Kadar İcraat Raporu 23 Nisan 1920-23 Eylül 1921), Yay. Haz. İsmail Hacıfettahoğlu, Türkiye Kızılay Derneği, Ankara 2009, s. 13.

${ }^{8}$ Besim Ömer, Hanımefendilere Hilâl-i Ahmer'e Dair Konferans, Türk Kızılayı Derneği, Ankara, 2009, s. 79-80.

${ }^{9}$ Mesut Çapa Kızılay (Hilâl-i Ahmer) Cemiyeti (1914-1925), Türk Kızılayı Derneği, 2. Baskı, Ankara, 2010, s. 15.

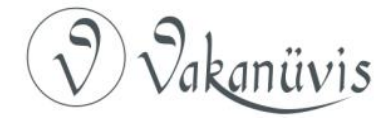


gerçekleşen nüfus değişimi olarak tanımlayabiliriz ${ }^{10}$. Türkiye ve Yunanistan arasındaki nüfus mübadelesi meselesi, ilk kez Balkan Savaşları'ndan sonra gündeme gelmiş ${ }^{11}$ ancak I. Dünya Savaşı'nın çıkması ile bu mesele çözülememiştir. ${ }^{12}$

Yunanlıların savaş yıllarında Türklere karşı uyguladıkları mezalimi savaş sonrasında da devam ettirmesi Türk-Yunan mübadelesini kaçınılmaz kılmaktaydı ${ }^{13}$. Ayrıca iki tarafında nüfus değişimine olumlu yaklaşması, meseleyi Lozan görüşmelerine taşıdı. Lozan görüşmelerinde, İtalyan Delegesi Montagna'nın başkanlığında, iki ülke temsilcilerinin katılımı ile bir alt komisyon kuruldu ${ }^{14}$.

Alt Komisyon'un çalışmalarının sonucunda, 30 Ocak 1923 tarihinde Türkiye ve Yunanistan arasında Türk-Yunan Nüfus Mübadelesi Sözleşmesi imzalanmıştır. Sözleşmeye göre, ìstanbul haricinde Türkiye'de oturan Rum nüfus ile Batı Trakya haricinde Yunanistan'da oturan Müslüman nüfusun mübadelesine Mayıs ayının başından itibaren başlanılacaktır ${ }^{15}$.

Sözleşme ve Protokol TBMM tarafından 23 Ağustos 1923'te onaylandı $^{16}$ ve iki gün sonra da yürürlüğe konuldu ${ }^{17}$. Sözleşmenin yürürlüğe girmesinin ardından mübadele işlerini bir düzene sokması

\footnotetext{
${ }^{10}$ Mustafa Sarı, "Mübadelede Hilâl-i Ahmer Cemiyetinin Faaliyetleri: Kocaeli Örneği (Ocak-Haziran 1924)", Uluslararası Karamürsel Alp ve Kocaeli Tarihi Sempozyumu II, C. I, Kocaeli Büyükşehir Belediyesi Yayınları, Kocaeli 2016, s. 481.

${ }^{11}$ Pınar Şenışık, “ 1923 Türk-Yunan Nüfus Mübadelesi: Erken Cumhuriyet Döneminde Modern Devlet Pratikleri ve Dönüşen Kimlikler", Studies of The Ottoman Domain, 6/10, Şubat 2016, s. 86.

12 İbrahim Erdal, "Türk Yunan Nüfus Değişiminde Türk Mübadillere Yapılan Yardım Faaliyetleri”, Ankara Üniversitesi Dil ve Tarih-Coğrafya Fakültesi Tarih Araştırmaları Dergisi, 25/40, Kasım 2006, s.202.

${ }^{13}$ Mustafa Sarı, “Mübadelede Hilâl-i Ahmer Cemiyetinin Faaliyetleri: Kocaeli Örneği (Ocak-Haziran 1924)", Uluslararası Karamürsel Alp ve Kocaeli Tarihi Sempozyumu II, C. I, Kocaeli Büyükşehir Belediyesi Yayınları, Kocaeli 2016, s.481.

${ }^{14}$ Kemal Arı, Büyük Mübadele (Türkiye'ye Zorunlu Göç), Tarih Vakfı Yurt Yayınları, 2. Baskı, İstanbul, 2000, s.17.

${ }^{15}$ Seha Meray, Lozan Barış Konferansı (Tutanaklar Belgeler), Ankara Üniversitesi Basımevi, cilt.1, Kitap.2, Ankara 1970, s. 6.

${ }^{16}$ TBMM Zabıt Ceridesi, Devre: 1, C. I, s. 282.

17 Mesut ÇAPA, "Mübadelede Kızılay (Hilâl-i Ahmer) Cemiyetinin Rolü", Sosyal Bilimler Enstitüsü Dergisi, Sayı:10,2001, s. 29.
}

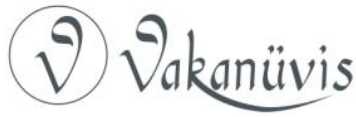


için 13 Ekim 1923'te Mübadele İmar ve İskân Vekâleti kuruldu ${ }^{18}$. Mübadele Vekâletinin başına Mustafa Necati Bey getirildi. Daha sonraki süreçte, Mahmut Celal Bayar, Refet Bele ve Recep Peker de bu görevi üstlenmiştir ${ }^{19} .8$ Kasım tarihinde de Mübadele İmar ve İskân Kanunu kabul edildi. Kanuna göre, vekâlet gelecek mübadillerin iskân, iaşe ve nakil işlerinin yanı sıra iskân mıntıkalarını belirlemek ve memleketin harap olan yerlerini onarmakla vazifelidir. ${ }^{20}$

Mübadele işlerinin getireceği yükümlülüğü hafifletmek isteyen Vekâlet, bu süreçte kendisine yardımcı olması için Hilâl-i Ahmer Cemiyeti ile görüşmelere başladı. Bu görüşmeler sonucunda Hilâl-i Ahmer Cemiyeti'nin Yunanistan'daki ihraç kapılarının her birinde sıhhî heyetleri kurması ve muhtaç durumda olan mübadillerin iskân, iaşe, giyim ve tedavi ihtiyaçlarını karşılaması kararlaştırıldı ${ }^{21}$.

Türk Hükümeti'nin Hilâl-i Ahmer Cemiyeti'ne verdiği yukarıda zikredilen vazifelerden de anlaşılacağı üzere, mübadele zamanında gerek Yunanistan'da ve gerek Türkiye'de iskelelere yakın bölgelerde sıhhî heyetleri kurulacaktı. Bu heyetler mübadillerin iaşe, giyim, ilaç ve tedavi gibi ihtiyaçlarını karşılayacaktır.

Mübadele İmar ve İskân Vekâleti ile Hilâl-i Ahmer'in ortak çalışmalarıyla mübadele işleri Ekim 1923'ten itibaren başlamıştır. Cemiyet, kendisine verilen vazifeler doğrultusunda farklı bölgelerde sıhhî heyetleri kurmuştur. Bu heyetlerden biri de Selanik 27. İmdad-ı Sıhhî Heyetidir. Gerek 27. İmdad-ı Sıhhî Heyetinin ve gerek diğer heyetlerin çalışmaları ile 1923-1927 yılları arasında Türkiye'ye 456.720 mübadil gelmiştir ${ }^{22}$.

\footnotetext{
${ }^{18}$ TBMM Zabıt Ceridesi, Devre: II, C. II, S.621-664.

${ }^{19}$ Mustafa Sarı, Izmit'te Hilâl-i Ahmer Cemiyeti (1911-1925), Babıali Kültür Yayıncılığı, İstanbul, 2016, s.231.

${ }^{20}$ Mustafa Sarı, "Mübadelede Hilâl-i Ahmer Cemiyetinin Faaliyetleri: Kocaeli Örneği (Ocak-Haziran 1924)", Uluslararası Karamürsel Alp ve Kocaeli Tarihi Sempozyumu II, C. I, Kocaeli Büyükşehir Belediyesi Yayınları, Kocaeli 2016, s. 481-482.

${ }^{21}$ Kızılay Arşivi, Dosya Numarası: 1335/120 (bundan sonraki sayfalarda Kızılay Arşivi, "KA" kısaltması ile belirtilecek).

22 Gökçe Bayındır Goularas, "1923 Türk-Yunan Nüfus Mübadelesi ve Günümüzde Mübadil Kimlik ve Kültürlerinin Yaşatılması”, Alternatif Politika, 4/2, 2012, s. 132
} 
Hilâl-i Ahmer Cemiyeti ile alakalı son dönemlerde çok sayıda yayın yapılmasına rağmen, Hilâl-i Ahmer Cemiyeti Selanik 27. İmdad-ı Sıhhî Heyeti'nin faaliyetleri konusunda herhangi çalışma bulunmamaktadır. Kızılay Arşivi, Türkiye Hilâl-i Ahmer Mecmuası, Hilâl-i Ahmer Cemiyeti tarafından hazırlanan raporlar, TBMM Zabıt Cerideleri ve araştırma eserleri incelenerek hazırlanan bu çalışmanın literatürdeki boşluğu doldurması amaçlanmaktır.

\section{Heyetin Teşkili ve Selanik'e Hareketi}

Hilâl-i Ahmer Cemiyeti 27. Imdad-ı Sıhhî Heyeti, Ekim 1923 ayı içerisinde Sertabip Mahir Bey'in başkanlığında kuruldu. Heyetteki diğer görevliler şu şekildedir: Tabip Cemal Namık, Kemal ve Hüseyin Avni Beyler, Eczacı İbrahim İhsan Efendi, İdare Memuru Feridun Bey, Ambar Memuru Cevat Efendi, Sevk Memuru Sait Efendi, ikisi bayan dördü erkek altı hastabakıcı, Ser Hademe Hüseyin Efendi, Hademe Hacı Rasim Efendi, Memur Arif ve Sait Arif Beyler ${ }^{23}$.

27. İmdad-ı Sıhhî Heyeti, İstanbul'dan 18 Ekim 1923 tarihinde hususi bir vapurla ayrılmıştır ${ }^{24}$. Heyet, 24 Ekim'de görev mahalli Selanik'e ulaşmıştır ${ }^{25}$. Limanda Yunan Kızılhaç ve sağlık yetkilileri tarafından karşılanan heyet, bir otele yerleştirilmiştir ${ }^{26}$.

Aslında 27. İmdad-ı Sıhhî Heyeti'nden önce, Hilâl-i Ahmer Cemiyeti tarafından mübadele işlerindeki karışıklıkları çözmek için teşkil edilen Muhtelit Komisyonu'na Hilâl-i Ahmer Murahhası olarak tayin edilen Doktor Ömer Lütfü Bey ile Kâtibi Cevdet Bey Selanik'e gönderilmişti ${ }^{27}$. Ömer Lütfü Bey'in görevi gerektiğinde merkez ile de görüşerek muhtemel sorunlara çözüm bulmak, gözlemlerini merkeze bildirmek ve Yunanistan'da kurulan İmdad Heyetleri ile birlikte hareket etmektir ${ }^{28}$.

\footnotetext{
${ }^{23}$ KA, Ds. $1335 / 6$ lef: 10.

${ }^{24}$ Murat Uluğtekin, M. Gül Uluğtekin, Osmanlı'dan Cumhuriyet'e Hilâl-i Ahmer Icraat Raporları 1914-1928, Pulat Basımevi, Ankara 2013, s.359.

${ }^{25}$ KA, Dosya No: 1335/ 7.

26 Mesut Çapa, "Mübadelede Kızılay (Hilal-i Ahmer) Cemiyetinin Rolü", Sosyal Bilimler Enstitüsü Dergisi, Sayı: 10, Yıl: 2001, s.36.

27 THAM, No: 26, 15 Ekim 1923, s.385.

${ }^{28}$ Murat Uluğtekin, M. Gül Uluğtekin, Osmanlı'dan Cumhuriyet'e Hilâl-i Ahmer Icraat Raporları 1914-1928, Pulat Basımevi, Ankara 2013, s.359.
}

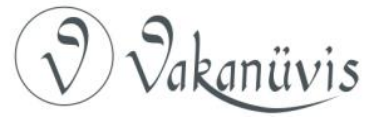




\section{27. İmdad-ı Sıhhî Heyeti'nin Ekim-Aralık 1923 tarihlerindeki}

\section{Faaliyetleri}

27. İmdad-ı Sıhhî Heyeti Selanik'e vardığında, şehirde Türkiye'ye sevk edilmeyi bekleyen mübadillerin durumu hiç de iç açıcı değildi. Daha ilk günlerde bir an evvel sevk edilmek ümidiyle şehre gelen mübadillerin miktarı 10.000 kişiye yaklaşmıştı. Bunların birçoğu kalacak yeri olmadığı için sokaklarda yatmaktaydılar. Bununla birlikte, Yunan Hükümeti'nin faaliyete geçirdiği müsadere uygulaması sonucunda mübadillerin tüm mallarına el konulması, onların sefaletini daha da artırmıştı $^{29}$.

Mübadillerin sıhhî şartlarının uygunsuzluğunun dışında, aç, sefil ve perişan bir halde soğuk havada dışarıda kalmalarından dolayı heyeti zorlu bir süreç bekliyordu. Mübadillerin tedavisi için dispanser olarak kullanılmak üzere Yunan makamlarının da yardımı ile Islahhane yanındaki Türk Eytamhanesi'nin idare dairesinden 3-4 oda heyet emrine verilmişti. Eytamhane'deki dispanserin dışında mübadiller için Akça Mescit'te bir tane daha dispanser tesis edilmişti. Dispanserlerin kurulmasının dışında iaşe sorunları için de Islahhane civarında küçük bir aşhane açılmıştı ${ }^{30}$. Dispanserlerde 30 Ekim-8 Kasım arasında 2.240 kişi muayene edilmiş ${ }^{31}$ ve aşhanede de 2.900 kişinin iaşe ihtiyacı giderilmiştir $^{32}$. Heyet, mübadillerin iskân meselesi için de hemen çadırlı iskân yerleri oluşturmuştur ${ }^{33}$. 27. İmdad-ı Sıhhî Heyeti'nin kurduğu dispanserlerin ve aşhanenin hemen vazifeye başladığı ve mübadillerin sağlık ve iaşe meselelerinin dışında iskân sorununun da yavaş yavaş çözülmeye çalışıldığı görülmektedir.

Kasım ayının ortalarında, sadece Türkiye'ye sevk edilmek için bekleyen mübadillerin miktarı 25.000'i geçmişti. Üstelik bu mübadillere ilaveten Anadolu'dan Yunanistan'a gelen 100.000'e yakın Rum mübadilinin de Selanik'e yerleştirilmesi, durumun daha da ciddi bir hal almasına neden olmuştu. Çünkü bu mübadiller arasında emraz-ı

\footnotetext{
${ }^{29}$ KA, Ds. 1296/ 212.

${ }^{30}$ KA, Ds. 1297/ 131.

${ }^{31}$ KA, Ds. 1296/ 225.

32 THAM, NO: 28, 15 Aralık 1923, s. 106

${ }^{33}$ KA, Ds. 1296/ 212.
}

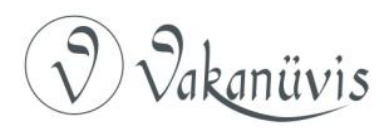


sâriye (salgın hastalık) baş göstermesi durumunda bütün şehir bundan etkilenecekti ${ }^{34}$. Yukarıdaki anlatılan durumdan da anlaşılacağı üzere, Kasım ayı ortalarında Selanik'teki mübadillerin sorunlarının başında iskân meselesi gelmekteydi. Nitekim 14 Kasım 1923 tarihinde Islahhane civarında açıkta yatan üç kişinin vefat etmesi tehlikenin boyutunu ortaya koymaktadır ${ }^{35}$.

Bu durum karşısında heyet, mübadilleri yerleştirmek için çadırlı iskân yerlerinin dışında cami ve medreselerden de faydalanma yoluna gitmiştir $^{36}$. Bu tür tedbirlerin yeterli gelmeyeceğini düşünen Heyet, bunun dışında Kireç Köyü Kara Hüseyin istikametinde 5.000 kişilik bir çadır kamp kurma çalışmalarına da başlamıştır. Çadırların etrafına abdesthaneler yapılarak temiz su ihtiyacı da karşılanmaya ve bu suretle salgın hastalıkların önüne geçilmeye çalışılmıştı ${ }^{37}$. Cami ve medreselerin iskâna açılması ile Kireç Köyü kampının kurulması, mübadillerin iskân sorununu bir nebze rahatlatmış ise de her gün şehre yüzlerce mübadilin gelmesi, iskân sorununun tam olarak çözülmesine olanak vermiyordu. Bu durum Selanik Heyeti Başkanı Mahir Bey ile Muhtelit Komisyon Hilâl-i Ahmer Murahhası Ömer Lütfü Bey'in yeni çözüm arayışları içerisine girmesine neden olmaktaydı. Sonunda Gülbaba mevkiinde yeni bir çadırlı iskân yeri kurulmasına karar verildi ${ }^{38}$.

Mübadillerin sağlık sorunları için dispanserlerin dışında bir hastane de gerekliydi. Heyet, Selanik'e geldiğinden beri bir hastanenin açılması için yoğun mesai harclyordu. Nihayet, 17 Kasım 1923 tarihinde hastanenin açılışı gerçekleştirildi ${ }^{39}$. Aşhane ise mübadillere hizmet

${ }^{34}$ KA, Ds. $1257 / 158$.

35 Mesut Çapa, "Mübadelede Kızılay (Hilal-i Ahmer) Cemiyetinin Rolü", Sosyal Bilimler Enstitüsü Dergisi, Sayı: 10, Yıl: 2001, s. 38

${ }^{36}$ KA, Ds. 1296/ 212.

${ }^{37}$ KA, Ds. 1256/ 212 lef: 2.

38 Mesut Çapa, "Mübadelede Kızılay (Hilal-i Ahmer) Cemiyetinin Rolü”, Sosyal Bilimler Enstitüsü Dergisi, Sayı: 10, Yıl: 2001, s. 38

39 Mesut ÇAPA, “Mübadelede Kızılay (Hilâl-i Ahmer) Cemiyeti'nin Rolü”, Sosyal Bilimler Enstitüsü Dergisi, S. 10, 2001, s.37-38.

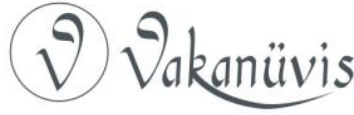


vermeye devam etmekteydi. 9 Kasım'dan ay sonuna kadar günde ortalama 750 kişiye aşhaneden yemek dağıtı $ı$ ıştır ${ }^{40}$.

Kasım ayı ortalarında 27. İmdad-ı Sıhhî Heyeti, Selanik'te mübadiller için bir hastane, iki dispanser, bir aşhane, üç çadır kamp açarak mübadillerin sağlık, iaşe ve iskân sorunlarını gidermeye çalışmıştır. Ancak asıl yapılması gereken Selanik'te biriken mübadillerin bir an önce Türkiye'ye sevkleriydi. Nitekim Kasım ayının sonlarında Selanik'te bulunan ve Türkiye sevk edilmeyi bekleyen mübadillerin miktarı 30.000 'i aşmıştı ${ }^{41}$. Şu ana kadar mübadil sevk edilememesinin nedeni, sevkiyatı gerçekleştirecek gemi bulunamamasıydı. Bu sorun, Mübadele İmar ve İskân Vekâleti'nin Türk Armatörleri ve Seyr-i Sefain İdaresi ile yaptığı anlaşma ile çözülebilmiştir. Bu anlaşma ile vekâletin emrine o zaman için 17 gemi verilmişti. Ayrıca mübadillerin sevkiyatı daha uygun fiyatlarda gerçekleşecekti ${ }^{42}$.

Mübadele İmar ve İskân Vekâleti'nin yaptığı anlaşma ilk meyvelerini vermeye başladı. Nitekim 22 Kasım'da Arslan Vapuru ile Selanik'ten Tekfurdağı'na ilk sevkiyat gerçekleştirildi. ${ }^{43}$ Sevk işlemlerinin 26 ve 30 Kasım tarihlerinde de devam etmesi ile ayın sonunda Tekfurdağı'na 6.352 mübadil sevk edilmiş oldu ${ }^{44}$. Sevkiyat sırasında, herhangi bir problemle karşılaşmamak için 27. İmdad-ı Sıhhî Heyeti tarafından mübadillere aşı ve pasaport işlemleri uygulanmaktaydı. Ayrıca gemilere alınan mübadillerden durumları iyi olanların sefer ücretlerini kendilerinin karşılaması isteniliyordu. Durumu olmayanların masrafları ise hükümetlerince karşılanıyordu ${ }^{45}$.

Kasım ayının son haftasından itibaren sevk işlerinin hızlanması ile Aralık ayında 16.792 mübadil sevk edilmiştir. Bu mübadillerin çoğunluğu Tekfur Dağı, İzmir ve Mudanya'ya gönderilmiştir ${ }^{46}$. Bu arada sevk işlerindeki bazı uygunsuz durumların Ömer Lütfü Bey'e iletildiğini

\footnotetext{
${ }^{40}$ THAM, NO: 28, 15 Aralık 1923, s. 107.

${ }^{41}$ KA, Ds. 1335/ 23.

42 Mesut Çapa, "Mübadelede Kızılay (Hilâl-i Ahmer) Cemiyeti'nin Rolü”, Sosyal Bilimler Enstitüsü Dergisi, S. 10, 2001, s. 42.

${ }^{43}$ KA, Ds. $1297 / 158$ lef: 4.

${ }^{44}$ THAM, NO: 29, 15 Ocak 1924, s. 143-144.

${ }^{45}$ THAM, NO: 28, 15 Kasım 1923, s. 66.

${ }^{46}$ THAM, NO: 28, 15 Aralık 1923, s. 105; THAM, NO: 29, 15 Ocak 1924, s.143-144.
}

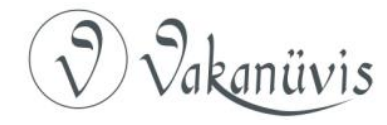


görüyoruz. Bu şikâyetlerden biri Selanik Heyeti Başkanı Mahir Bey hakkındadır. Buna göre Mahir Bey fakir mübadillerden fazla sevk ücreti alırken zengin mübadillerin bazılarını fakir olarak göstererek ücretsiz sevklerini sağlıyordu. Bu konu hakkında soruşturma istenmiş ${ }^{47}$ ise de olayın çok büyütülmediği Mahir Bey'in göreve devam etmesinden anlaşılmaktadır.

\section{Ocak-Şubat 1924 Tarihlerindeki Faaliyetler}

Heyet, göreve başladıktan sonra ocak ayına kadar, aralıksız olarak çalışarak mübadillerin iskân ve iaşe sorunlarını çözmeye çalışmıştır. Ocak ayından itibaren, hava şartlarının ağırlaşması zaten zor durumda olan mübadillerin toplu bir şekilde iskânını ve iaşesini mecbur kılmıştı. Bunun nedeni, şehrin farklı bölgelerinde yardıma muhtaç durumda olan mübadillerin fazlalığıydı ${ }^{48}$. Selanik'teki mübadillerin dışında, Vodina, Yenice, Karacaova, Karaferye gibi birçok bölgeden de 27. İmdad-ı Sıhhî Heyeti'ne yardım müracaatları yapılmaktaydı. Buralarda ailesini kaybeden kimsesizler, tedaviye muhtaç ağır hastalar ve açıkta yatan kimseler bulunmaktaydı ${ }^{49}$. Çözüm bu çaresiz insanların bir an önce Selanik'e nakilleriydi. Hilâl-i Ahmer Cemiyeti Genel Merkezi de Selanik'e 200 kadar yeni çadır göndererek bu mübadiller için hazırlıklarını yapmıştı. Bu yeni gelen çadırlar ile birlikte Selanik'te 300 'den fazla çadır mübadillerin iskânı için kullanılmaya başlanmıştı. ${ }^{50}$. Ömer Lütfü Bey'in ifadesine göre mübadillerin iskânı için kurulan bu mıntıkalar şehrin en iyi bölgelerindeydi. Böylece binlerce mübadil sokaklarda kalmaktan kurtarıldığı gibi salgın hastalıkların da önüne geçilmişti ${ }^{51}$.

27. İmdad-ı Sıhhî Heyeti'nin aldığı tüm önlemlere rağmen, Selanik'te bulunan mübadillerin iskân meselesi tam olarak çözülememekteydi. Bu durum da bazı olumsuz vakıaların yaşanmasına neden olmaktaydı. Nitekim iskân mıntıkalarının dışındaki yerlerde elverişsiz şartlardan dolayı, mübadillerin bebekleri doğumdan sonra

\footnotetext{
${ }^{47}$ KA, Ds. $1257 / 51$ lef: 5.

${ }^{48}$ KA, Ds. $1256 / 212$ lef: 1.

${ }^{49}$ Daha detaylı bilgi için bkz: KA, 1335/ 258; KA, 1335/ 259; KA, 1335/ 294, lef: 1; KA, 1335/ 294 lef: 3; KA, 1335/ 287, lef: 2.

${ }^{50}$ KA, Ds. $1256 / 212$ lef: 2.

${ }^{51}$ THAM, NO: 30, 15 Şubat 1924, s. 199.
}

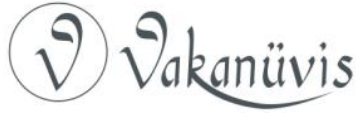


ancak birkaç gün hayatta kalabilmekteydi. Bu durum Heyetin yeni birtakım önlemler almasına neden olmuştu. Bu amaçla hamileler için ayrı bir dispanser tesis edilmiş ve bu dispanserlerde ücretsiz olarak tedavi edilmişlerdir ${ }^{52}$. Bunun dışında, heyet, hastane ve dispanserlerdeki çalışma günlerini arttırmıştı. Önceden dispanserlerde cuma günleri hasta kabul edilmezken, merkezden gelen emir üzerine dispanserler cuma günleri de çalışmaya başlamıştır ${ }^{53}$. Dispanserlerdeki mesainin artması ile ocak ayında 3.350 hasta muayene edilmişti ${ }^{54}$. Hastanede ise ocak ayı istatistiklerine göre, aralık ayından kalan 19 hastanın dışında 46 hasta daha tedavi altına alınmıştır. Bunlardan 27'si iyileşmelerinin ardından taburcu edilirken $24^{\prime}$ ü vefat etmiştir ${ }^{55}$.

Şubat ayı, hastane ve dispanserlerin ocak ayına göre daha yoğun çalıştığı bir dönemdir. Çünkü sevk edilen mübadillerinin aşıları da Selanik Heyeti tarafından gerçekleştirilmekteydi. Şubat ayının ilk haftasında, dispanserlerde 615 hasta muayene edilirken bunların $11^{\prime} i$ vefat etmiştir ${ }^{56}$. Ayın ikinci haftasında 550 kişi muayene edilmiş ve bunlardan 9'u vefat etmişti. Bu süre zarfında 1.787 mübadile çiçek ve dizanteri aşıları yapılmıştır ${ }^{57}$. Şubat'ın üçüncü haftasında, 442 hasta muayene edilirken 2 kişi vefat etmiş, 1.733 kişiye çiçek ve dizanteri aşıları uygulanmıştır ${ }^{58}$. Ayın son haftasında ise 192 kişinin muayenesi gerçekleşirken 11 kişi vefat etmiştir. Ayrıca 3.144 kişiye çiçek ve dizanteri aşıları yapılmıştır ${ }^{59}$. Böylece şubat ayında toplamda 1.799 hasta muayene edilirken 6.664 kişiye çiçek ve dizanteri aşıları yapılmıştır. Bunların 33'ü vefat etmiştir.

Heyet'in faaliyetlerinin yoğunlaştığı bu dönem de iaşeye muhtaç durumda olan mübadillerin miktarı da her geçen gün artmaktaydı. Heyet, bu mübadillerin ihtiyaçlarını günlük olarak karşılamak için tüm imkânlarını kullanıyordu. Nitekim ocak ayı boyunca günde ortalama

${ }^{52}$ THAM, NO:29, 15 Ocak 1924, s. 144.

${ }^{53}$ KA, Ds. 1335/ 126.

${ }^{54}$ KA, Ds.1335/ 282 lef: 2.

${ }^{55}$ KA, Ds. $1335 / 282$ lef: 3

${ }^{56}$ KA, Ds. 1335/ 250 lef: 3.

${ }^{57}$ KA, Ds. 1335/ 264.

${ }^{58}$ KA, Ds. $1335 / 250$ lef: 9.

${ }^{59}$ KA, Ds. $1335 / 250$ lef: 5.

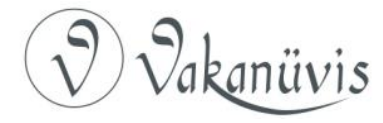


774 mübadil iaşe edilmişti. Ay sonunda bu rakam toplamda 24.002'yi bulmuştu. Dağıtılan yemek cinsleri ise günlük olarak farklılık göstermekteydi. Mübadillere etli un çorbası, etli mercimek, fasulye, patates, pirinç, makarna gibi yemeklerin dağıtıldığı görülmektedir ${ }^{60}$. Şubat ayına gelindiğine, Selanik'te bulunan mübadillerin sayısına paralel olarak heyetin daha fazla mübadilin iaşe ihtiyaçlarını karşılamak zorunda kaldığı görülmekte. Nitekim şubat ayının 1. haftasında $8.694^{61}$, 2. haftasında $8.078^{62}, 3$. haftasında $8.137^{63}$ ve son haftasında 7.950 kişi $^{64}$ iaşe edilmiştir. Böylece şubat ayı boyunca iaşe dağıtılan mübadilin miktarı 32.859'i bulmuştur. Sonuç olarak, ocak ve şubat aylarında Selanik Heyeti, toplamda 56.861 kişilik iaşe ihtiyacını karşılamıştır.

Yukarıda belirtildiği gibi mübadillerin iaşe ve tedavi intiyaçları karşılanırken sevk işlemleri de devam etmekteydi. Ocak ayında ilk sevkiyat 4 Ocak tarihinde gerçekleşti ve ayın sonuna kadar 2-3 günde bir Selanik Limanı'ndan gemi hareket etti. Bu sevkiyatların sonucunda 15.939 mübadil Tekfurdağı, Bandırma, Mudanya gibi şehirlere sevk edildi $^{65}$. Böylece 1 Şubat 1924 tarihine kadar Selanik'ten 36.402 Mübadil Türkiye'ye sevk edilmiş oldu ${ }^{66}$. Sevk işlemleri şubat ayında da devam etmiştir. Ayın başında, Sulh Vapuru ile 1.540, Akdeniz Vapuru ile 2.200 mübadil, 460 manda ve öküz, 1.350 koyun ve mübadillerin eşyaları İzmit'e sevk edilmişti ${ }^{67}$. İzmit'e sevk işlemini gerçekleştiren Sulh Vapuru, Selanik Limanı'na geri dönerek 14 Şubat tarihinde 1.237 kişiyi daha Türkiye'ye sevk etmiştir ${ }^{68}$. Ayın sonlarında da sevk işlemleri devam etmiş ve 24 Şubat'ta Antalya Vapuru ile 1035 mübadil Türkiye'ye sevk edilmiştir ${ }^{69}$.

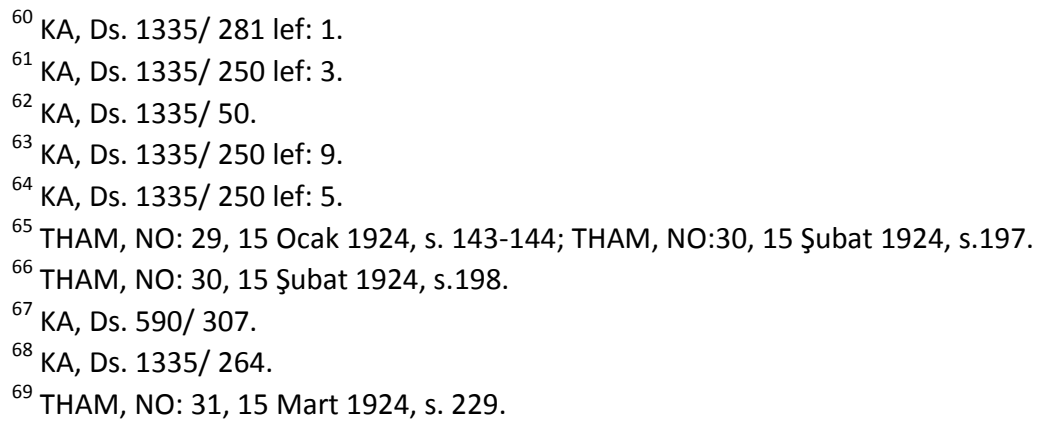




\section{Mart ve Nisan 1924 Ayındaki Faaliyetleri}

Mart ayında da Vodina, Karacaova, Yenice, Mayadağ, Karaferye, Langaza, Poroy ve başka bölgelerden mübadeleye tabi ahali arasında açlık bulunduğuna dair neredeyse her gün Selanik Heyeti'ne dilekçeler gelmekteydi. Ancak heyet, ne yeterli ulaşım araçlarına ne de bu yoksul halkın hepsinin ihtiyacını karşılayabilecek erzaka sahipti. Durumdan haberdar edilen Mübadele Vekâleti, bu mahallerdeki yoksulların iaşelerinin sağlanması için Kayalar ve Kozana Heyetlerini de görevlendirdi ${ }^{70}$.

Yunanistan'da bulunan diğer heyetlerin de çalışmalarına rağmen iaşe edilecek nüfusun her gün artmasından dolayı heyetin masrafları da artmaya başlamıştı. Limandan gemi kalkmadığı günlerde günlük olarak 2.000 ekmek dağıtılması yeterli iken büyük gemilerin hareketi sırasında bu rakam 2-3 kat artabilmekteydi. Merkeze gönderilen rapordan da anlaşılacağı üzere sadece günlük ekmek harcamaları için 18.000 frank gerekmekteydi ${ }^{71}$. Ekmek masraflarını kısmak için Yunan Hükümeti'nin yardımları görülmüş ise de heyet, ekmeği kendisinin yapmasının daha uyguna geleceğini düşünmekteydi. Çünkü mübadele işleri için gelen erzaktan gümrük alınmamaktaydı ${ }^{72}$. Bu şekilde ekmek masraflarının düşürülmesine çalışılırken, bunun yeterli olmayacağını düşünen heyet, günlük olarak iaşe edilecek mübadil miktarını da en fazla 1.000 mübadille sınırlandırılmasına karar verdi ${ }^{73}$. Bu karar Nisan ayında da uygulanmıştır ${ }^{74}$. Alınan bu karara rağmen, günlük 1.000 kişiden fazlasına iaşe dağıtıldığı görülmektedir. Örneğin yalnızca 7-13 Mart tarihleri arasında kamp, Islahhane, rıhtım ve vapurlarda 13.452 kişi iaşe edilmiştir ${ }^{75}$. İaşe işlerinin bu denli yoğun gitmesi 11 Nisan tarihine kadar devam etmiş ancak söz konusu tarihten sonra bir rahatlama meydana gelmiştir. Nitekim 28 Mart'tan 11 Nisan'a kadar

\footnotetext{
${ }^{70}$ KA, Ds. 1352/ 10 lef: 2.

${ }^{71}$ KA, Ds. 1335/ 322.

72 KA, Ds. 1352/ 64.

${ }^{73}$ KA, Ds. $1352 / 48$.

${ }^{74}$ KA, Ds. 1335/ 366; KA, 1335/ 373.

${ }^{75}$ THAM, NO: 32, 15 Nisan 1924, s. 264.
}

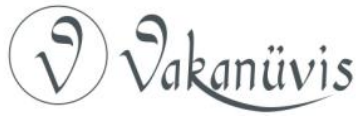


33.772 kişi iaşe edilirken ${ }^{76} 11$ Nisan'dan itibaren ayın sonuna kadar 9.700 kişinin iaşe ihtiyaçları karşılanmıştı ${ }^{77}$.

İaşe işlerinin yanında, Selanik'te neredeyse her iş Hilâl-i Ahmer Cemiyeti 27. İmdad-ı Sıhhî Heyeti'nden beklenilmekteydi. Cenaze işleri de buna dâhildi. Şehrin muhtelif bölgelerinde vefat eden Türk mübadillerin cenazeleri, Islahhaneye getiriliyordu. Bu durum heyetin masraflarının daha da artmasına neden olmuştu. Çünkü kişi başına nakil ve defin işlemleri ortalama 120 Frank tutmakta ve ayda 30-40 bin dirhem sadece cenaze masraflarına harcanmaktayd ${ }^{78}$.

Mart-Nisan aylarında ortaya çıkan bir başka sorun, tabip sıkıntısıydı. Selanik civarında bazı verem ve çiçek vakalarının görüldüğü bu tarihlerde ${ }^{79}$, Avni ve Celal Beylerin tayini ile Heyet kadrosunda tabip olarak yalnızca Abdülkadir İsmet Bey kalmıştı. Limandan bir gemi kalktığı takdirde Abdülkadir Bey'de bu gemide görevlendirileceğinden, Selanik'te hiç tabip kalmaması söz konusu olmuştu. Hastane ve dispanserlerin yoğun mesai harcadıkları bu dönemde tabip sorununu çözmek için Celal Bey yerine Fazıl Bey tayin edilirken ${ }^{80}$ Kavala'dan Mustafa Bey ile İstanbul'dan Cemil Bey Selanik'e gönderilmiştir ${ }^{81}$.

Tabip sıkıntısının halledilmesi ile dispanserler ve hastaneler faaliyetlerini yoğunlaştırmış, aşı işlemleri arttırılmıştı. Mart ayında, dispanserler ve hastanede 2540 hastanın tedavisi gerçekleşmiştir. Bunlardan 104'ü vefat etmiştir ${ }^{82}$. Nisan ayında da dispanser ve hastaneler aynı hızla faaliyetlerini devam ettirmiştir. Gayrimüslimler dâhil olmak üzere 1937 hasta tedavi altına alınırken bunların 75'i vefat etmişti ${ }^{83}$. Mart ve Nisan aylarında salgın hastalıkların önüne geçmek için de aşılama faaliyetlerine devam edilmiş ve Mart ayında 23.117

${ }^{76}$ KA, Ds. 1335/ 162 lef: 1, 1335/ 359.

${ }^{77}$ KA, Ds. 1335/ 161 lef: 1, 1335/ 161 lef: 5.

${ }^{78}$ KA, Ds. $1335 / 322$.

${ }^{79}$ KA, Ds. $1335 / 265$.

${ }^{80}$ KA, Ds. $1352 / 64$.

${ }^{81}$ KA, Ds. $1352 / 99$.

${ }^{82}$ KA, Ds. 1335/ 326 lef: 1; KA, 1335/ 325; KA, 1335/ 327; KA, 1335/ 341 lef: 1; KA, 1335/ 328 lef: 3; THAM, NO: 32, 15 Nisan 1924, s. 264.

${ }^{83}$ KA, Ds. $1335 / 361$ lef: 1, KA, 1335/ 361 lef: 3, KA, 1335/ 361 lef: 5, KA, 1335/ 328 lef: 2.

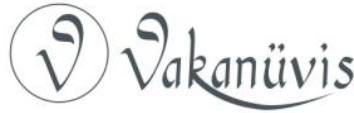


kişiye çiçek ve dizanteri aşıları, Nisan ayında ise 12.534 kişiye çiçek, 24.556 kişiye de dizanteri aşıları yapılmıştır ${ }^{84}$.

Aşılanma faaliyetlerine rağmen sevk edilen mübadiller arasında bulaşıcı hastalıklar görüldüğüne dair şikâyetler bulunmaktaydı. Örneğin, 8 Mart'ta Selanik'ten 1.483 mübadil ile hareket eden Sulh Vapuru hakkında bu yönde şikâyetler mevcuttu ${ }^{85}$. Bunun dışında, Nisan ayının başlarında Kozana ve Kayalar da tifüs vakalarının görülmesinden dolayı, vapurlara alabileceğinden fazla yolcu alınmaması ${ }^{86}$ ve Selanik Limanı'ndan hareket edecek vapurların tahaffuzhanelere uğramaları istenilmiştir ${ }^{87}$. Imdad Heyeti bu faaliyetleri ile bulaşıcı hastalıkların yayılmasını önlemeye çalışmaktaydı.

\section{Mayıs-Haziran 1924 Tarihlerindeki Faaliyetler}

Mayıs 1924 ayında da mübadiller arasında görülen salgın hastalıkların devam etmesi üzerine Hilâl-i Ahmer Merkezi, mübadillerin aşılarının eksiksiz yapılması için yeni aşılar göndermekteydi ${ }^{88}$. Ancak bu aşıların yetersiz kalması durumunda 27. İmdad-ı Sıhhî Heyeti'ne Selanik'ten aşı satın alma izni de verilmişti ${ }^{89}$. Ayrıca mübadiller arasında bir salgın felaketine yol açabilecek şüpheli kimselerin de karantina altında tutulması istenilmekteydi ${ }^{90}$. Salgın endişesinin olduğu bu dönemlerde Heyet'in tabip ve sağlık personeli sıkıntısı yaşamaması için bir hemşire ${ }^{91}$, bir hastabakıcı Selanik'e gönderilmiştir ${ }^{92}$. Daha sonra Heyet'e iki de tabip daha gönderilmesine rağmen, Selanik'te tabip sayısı beşe yükseldiği için bunlardan ikisinin başka yerlere tayin edilmesi istenilmiştir ${ }^{93}$.

Tabip ve hemşire sorunu kalmayan hastane ve dispanserlerde mübadillerin tedavilerine devam edilmiştir. Mayıs ayında,

\footnotetext{
${ }^{84}$ KA, Ds. $1335 / 328$ lef: 1.

${ }^{85}$ KA, Ds. $1352 / 62$.

${ }^{86}$ KA, Ds. 1335/ 182.

${ }^{87}$ KA, Ds. 21/ 171.

${ }^{88}$ KA, Ds. 1335/ 198; KA, 1335/ 216.

${ }^{89}$ KA, Ds. 1335/ 199.

${ }^{90} \mathrm{KA}$, Ds. $1335 / 216$.

${ }^{91}$ KA, Ds. 1335/ 198.

92 KA, Ds. 1335/ 216.

${ }^{93}$ KA, Ds. 1335/ 219.
} 
dispanserlerde 248'i Hristiyan olmak üzere 9.720 hasta muayene edilmiştir ${ }^{94}$. Hastanede ise geçen aydan kalan 10 hastanın yanı sıra mayıs ayında 45 hasta daha tedavi altına alınmıştır. Bunların 12'si taburcu olurken 22'si vefat etmiştir ${ }^{95}$. Hastalar arasında en çok görülen hastalığın sıtma olması ${ }^{96}$ Selanik'teki yaşam şartlarının kötülüğünü ortaya koymaktadır. Ayrıca mayıs ayındaki aşılama faaliyetleri ile birlikte toplam da 174.000 kişiye çiçek ve dizanteri aşıları tatbik edilmiştir. Daha sonradan gelen 25.000 kişilik aşı ile bu rakam 200.000 yaklaşmıştır ${ }^{97}$.

Mayıs ayına nazaran haziran ayında dispanserlerin faaliyetlerinde bir rahatlama meydana gelmiştir. Nitekim aralarında Müslüman olmayanlarında bulunduğu 1.517 hasta muayene edilmiştir ${ }^{98}$. Bu hastaların çoğunluğu erkektir ${ }^{99}$ ve en çok görülen rahatsızlık yine sıtmadır $^{100}$. Bunların dışında hastanede geçen aydan kalan 21 hastanın dışında 25 hasta daha tedavi altına alınmıştır. Bu hastalardan 17'si taburcu olurken 8'i vefat etmiştir ${ }^{101}$.

Heyetin bu dönemde iaşe yükümlülüğünün daha çok arttığı görülmüştür. Çünkü Mayıs ve Haziran ayları, heyetin faaliyete başladığından beri en fazla mübadilin iaşe edildiği dönem olmuştur. Nitekim mayıs ayında 43.963 kişi $^{102}$ haziran ayında ise 141.906 kişi iaşe edilmiştir $^{103}$. laş̧eye muhtaç mübadillerin artmasından dolayı, 27 Mayıs'a kadar her bir bireye günlük 320 gram ekmek dağıtılmış ise de 28 Mayıs'tan itibaren bu rakam 500 grama çıkmıştır. Ayrıca fasulye, nohut cinsinden yemekler ise 120 gramdan dağıtılmıştır ${ }^{104}$. İaşe

\footnotetext{
${ }^{94}$ THAM, NO: 34, 15 Temmuz 1924, s. 364.

${ }^{95}$ KA, Ds. $1335 / 406$ lef: 2.

${ }^{96}$ KA, Ds. $1335 / 406$ lef: 1.

${ }^{97}$ KA, Ds. 1335/ 198.

${ }^{98}$ KA, Ds. $1335 / 539$ lef: 1, 1335/ 539 lef: 2.

${ }^{99}$ KA, Ds. $1335 / 539$ lef: 1.

${ }^{100}$ KA, Ds. $1335 / 539$ lef: 2.

${ }^{101}$ KA, Ds. 1335/ 539.

${ }^{102}$ KA, Ds. 1335/ 383 lef: 2; KA, 1335/ 381; KA, 1335/ 382.

${ }^{103}$ KA, Ds. $1335 / 431,1335 / 460$ arası belgeler.

${ }^{104}$ KA, Ds. 1335/ 383 lef: 2; KA,1335/ 381; KA, 1335/ 382.
}

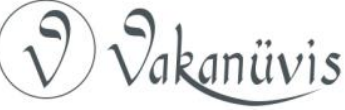


masraflarının arttığı bu dönemde merkez ambarından da 1.890 kilo dakik (un) gönderilmiştir ${ }^{105}$.

Mübadele işlerinin getirdiği ağır yükümlülüklere rağmen faaliyetlerini ara vermeksizin sürdüren Selanik Heyeti, sevk işlerini de kesintiye uğratmadan devam ettirmiştir. 12 Mayıs'ta 4.375 mübadil ile Akdeniz Vapuru, Selanik Limanı'ndan ayrılmıştır. Yine aynı tarihte Ankara Vapuru ile 1.800 mübadil Mersin'e sevk edilmişti ${ }^{106}$. 17 Mayıs'ta Sulh Vapuru ile 1.638 mübadil $^{107}$ Giresun Vapuru ile de 1.300 mübadil $^{108}$ Türkiye'ye sevk edilmiştir.

\section{Temmuz-Ağustos 1924 Tarihlerindeki Faaliyetler}

Temmuz ayında Selanik ve Patras'da veba vakıalarının görülmesi, Selanik'te kısa süreli paniğe yol açmıştı. Sıhhiye ve Muavenet-i Içtimaiye Vekâleti Selanik Heyeti'nden gerekli tedbirleri almasını istemiş ${ }^{109}$ olmasına rağmen Selanik'te veba aşısının bulunmaması heyeti çaresiz bırakıyordu ${ }^{110}$. Aşı sorununu çözmek için Hilâl-i Ahmer Merkezi'nden on bin kişilik çiçek, beş kilo dizanteri ve 5 kilo da veba aşısı gönderilmişti ${ }^{111}$. Ancak Temmuz ayı sonlarına doğru heyetin elindeki veba aşısının bitmesi nedeniyle, heyete 15 kilo daha veba aşısı gönderilmiştir $^{112}$.

Temmuz ve Ağustos aylarında hastane ve dispanserler de faaliyetlerini sürdürmüştür. Nitekim temmuz ayında dispanserlerde $576^{113}$ hastanede ise geçen aydan kalan 21 hastanın dışında 23 hastanın daha tedavisi gerçekleştirilmiştir. Bunlardan 5 'i vefat etmiş, $24^{\prime}$ ü de taburcu olmuştur ${ }^{114}$. Ağustos ayında ise dispanserler de $854^{\prime}$ ü kadın olmak üzere 1002 hastanın muayenesi gerçekleşmiştir. En çok

\footnotetext{
${ }^{105}$ KA, Ds. $1335 / 425$.

${ }^{106}$ KA, Ds. 1335/ 195.

${ }^{107}$ KA, Ds. 1256/ 115.

${ }^{108}$ KA, Ds. 1352/ 358.

${ }^{109}$ KA, Ds. 639/ 59.

${ }^{110}$ KA, Ds. 88/ 246.

${ }^{111}$ KA, Ds. 1335/ 228.

112 KA, Ds. 1335/ 237.

${ }^{113}$ KA, Ds. 1335/ 538.

${ }^{114}$ KA, Ds. 1336/ 3 Lef: 1.
}

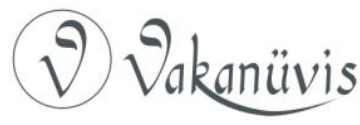


görülen rahatsızlık sıtmadır ${ }^{115}$. Sıtma hastalığının bu kadar sık görülmesinin nedeni temmuz ve ağustos aylarında havaların daha da ısınmasıydı. Bunların dışında hastanede geçen aydan kalan 15 hastanın dışında 28 hasta daha tedavi altına alınmış, bunlardan 5 'i vefat etmiştir $^{116}$.

Hastane ve dispanserlerin faaliyetleri sürerken iaşe işleri de devam etmekteydi. Heyet, görev süresinin sonlarına doğru yaklaşmasına rağmen iaşe edilecek nüfus halen artmaktaydı. Buna karşın, Heyet tüm imkânlarını kullanarak Temmuz ayında 93.400 kişinin ${ }^{117}$, Ağustos ayında ise 135.776 kişinin yemek ihtiyacını karşılamıştır ${ }^{118}$.

Bu dönemlerde, Heyet için tek sorun salgın hastalıklar ve iaşe edilecek nüfusun çoğalması değildi, ayrıca sevk işlemlerindeki istenmeyen durumlarla da mücadele etmekteydi. Mübadiller, sevk için limana gelen gemilere belirli kurallar dâhilinde bindirilirdi. Ancak bu dönemlerde sahte evrak kullanarak gemilere binenlere rastlanılmaktaydı ${ }^{119}$. Heyet'in bu problemi çözmek için sarf ettiği çabalar bir sonuç getirmemiştir. Çünkü sahte evrak ve para işleri o kadar yaygınlaşmış ki Selanik'ten Türkiye'ye giden bazı mübadillerin Türkiye'de bu sahte paraları kullandığı yönünde haberler gelmekteydi ${ }^{120}$.

Tüm bu olumsuz şartlara rağmen tüm imkânlarını kullanarak görevini sürdüren Selanik Heyeti, sevk işlemlerini ara vermeden sürdürmüştür. Sevk işlemlerinin başladığı tarihten itibaren Selanik Limanından 19 Temmuz'a kadar 99.720 mübadil Türkiye'ye sevk edilmiştir $^{121}$. 19 Temmuz'dan sonra Sakarya, Giresun ve Eminönü vapurları ile de Türkiye'ye sevkiyat yapılmıştır ${ }^{122}$. Sevk işleri Ağustos ayında da devam etmiş, 16 Ağustos'ta Timsah Vapuru ile İzmit ve

\footnotetext{
${ }^{115}$ KA, Ds. $1335 / 358$.

${ }^{116}$ KA, Ds. 1336/ 3.

${ }^{117}$ KA, Ds. 1335/ 507 ile 1335/ 537 arası belgeler.

${ }^{118}$ KA, Ds. 1335/ 601 ile 631 arası belgeler.

${ }^{119}$ KA, Ds. $1335 / 557$.

${ }^{120}$ KA, Ds. 1335/ 551.

${ }^{121}$ THAM, NO: 36, 15 Ağustos 1924, s.407.

122 KA, Ds. 1335/ 545; KA, 1335/ 548.
} 
İstanbul'a 20 Ağustos'ta Bahr-ı Cedit Vapuru ile Tekfurdağı'na mübadil sevkiyatı gerçekleşmiştir ${ }^{124}$.

\section{Eylül-Ekim 1924 Tarihlerindeki Faaliyetler ve Heyet'in Lağvedilmesi}

Eylül ayından itibaren sevk edilecek nüfusun azalması ve buna paralel olarak iaşe işlerinin hafiflemesinden dolayı Selanik Heyeti'nden Hilâl-i Ahmer Merkezi'ne gönderilen haftalık raporların artık gönderilmediği anlaşımaktadır. laş̧e ve sevk işleri ile alakalı muntazam raporlar tutulmamış ise de eylül ayına ait hastane ve dispanserlerin çalışmaları ile ilgili raporlar mevcuttur. Bu raporlara göre, dispanserlerde 1.238 hasta tedavi edilmiştir. Bunların $978^{\prime} i$ kadındı ${ }^{125}$. Bunların dışında hastanede geçen aydan kalan 15 hastanın dışında 28 hasta daha tedavi altına alınmıştır. Bu yatılı hastaların 5 'i vefat etmiştir ${ }^{126}$.

Eylül ayının sonlarında, Selanik Tali Komisyonu Türk Delegesinden gelen telgrafla, Selanik 27. İmdad-ı Sıhhî Heyeti'nin vazifesine 1 Ekim 1924 tarihinden itibaren son verileceği bildirilmiştir ${ }^{127}$. Bunun üzerine Heyet Reisi Esad Bey dâhil olmak üzere idare memuru, ambar memuru, kamp memuru ve diğer memur ve müstahdemler 11 Ekim'den itibaren Selanik'ten ayrılmaya başlamışlardır ${ }^{128}$. Heyet'in vazifesine son verilmesine rağmen, Selanik'te halen sevk edilecek mübadil bulunduğundan dolayı Hilâl-i Ahmer Cemiyeti'nden bir dispanser heyetinin Selanik'te göreve devam etmesi istenmiştir. Bu talebe kayıtsız kalmayan Hilâl-i Ahmer Cemiyeti, bir tabip ile hemşire bir hastabakıcı ve iki hademeden oluşan bir dispanser heyetini Selanik'te bırakmıştır ${ }^{129}$. Bu Heyet bazı sorunlar yaşasa da sevk işlerinin

\footnotetext{
${ }^{123}$ KA, Ds. 1296/ 691.

${ }^{124}$ KA, Ds. 1296/ 11.

${ }^{125}$ KA, Ds. 1335/ 538.

${ }^{126}$ KA, Ds. 1336/ 32.

${ }^{127}$ KA, Ds. $1257 / 70$ lef: 4.

${ }^{128}$ KA, Ds. 1336/ 13.

${ }^{129}$ THAM, NO: 38, 15 Ekim 1924, s.68.
}

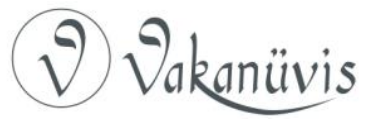


sonuna kadar da Selanik'te kalarak mübadillerin iaşe, sevk ve tedavi işlemlerini devam ettirmiştir ${ }^{130}$.

\section{Sonuç}

Mübadele sırasında gerek Mübadele İmar ve İskân Vekâleti'nin gerek Hilâl-i Ahmer Cemiyeti'nin önemli hizmetleri görülmüştür. Hilâl-i Ahmer Cemiyeti hem Türkiye'de hem de Yunanistan da sıhhîye heyetleri kurmuştur. Yunanistan'da kurulan heyetlerden en önemlisi Selanik 27. İmdad-ı Sıhhî Heyeti olmuştur.

24 Ekim 1923 tarihinde Selanik'te faaliyetlerine başlayan heyet, Ekim 1924 yılına kadar çok zor şartlar altında görevini yerine getirmiştir. Heyet, görev süresi boyunca yaklaşık 530.000 kişilik iaşe dağıtmıştır. Ancak hem mübadelenin ilk aylarında, hem de son aylarında bu hususta raporların muntazam olmamasından dolayı net bir rakam elde etmek zordur.

Yine merkeze gönderilen raporlardan anlaşılacağı üzere dispanserlerde ve hastanede 32.000 hasta muayene edilmiştir. Ancak aynı durumun burada da var olduğunu belirtmek gerekir. Dispanser ve hastane tutanaklarından vefat ve ölüm rakamlarını da görmek mümkündür. Ocak ayından ekim ayına kadar hastane ve dispanserler de 289 kişi vefat etmiş ve 35 doğum gerçekleşmiştir. Mübadillerin aşı işlemlerini de gerçekleştiren Selanik Heyeti, Mayıs 1924 tarihine kadar 174.000 kişiye çiçek ve dizanteri aşısı yapmıştır. Bu rakamların dışında, aynı ay içerisinde 25.000 kişilik çiçek ve dizanteri aşısı gelmiştir. Mayıs ayından sonra aşılama faaliyetlerine dair muntazam bir belge olmasa da bu bilgilerden yola çıkarak, Selanik'te 200.000 'den fazla mübadilin aşılandığını belirtebiliriz.

Selanik Limanı'ndan sevk edilen mübadillerin miktarını tam olarak saptamak zor olsa bile yaklaşık bir rakamı elde edebiliriz. 22 Kasım 1923 tarihinde mübadillerin Selanik'ten sevklerine başlanmış ve 19 Temmuz 1923 tarihine kadar 99.720 mübadil sevk edilmiştir. Sevk işlemlerinin en yoğun olduğu bu dönemlerde heyetin bu konuda

130 Örneğin, Ekim ayının sonlarında 950 mübadilin iaşesi gerçekleşmiştir (KA, Ds. $88 / 313)$.

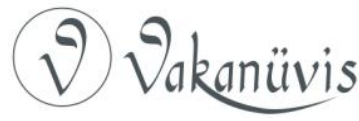


özenle raporlar hazırladığını görebiliyoruz. Ancak Ağustos ayından sonra sevk işlemlerinin yavaşlaması ile muntazam olarak raporların tutulmadığı ortadadır. Buna rağmen heyetin 1 Ekim 1924 tarihine kadar görevde kalması ve sevkiyatın devam etmesini göz bulundurursak, heyetin marifetiyle Selanik'ten 100.000 'in üzerinde mübadilin Türkiye'ye sevk edildiğini belirtebiliriz.

Kısaca, 23 Ekim 1923 tarihinde faaliyete başlayan Selanik 27. İmdad-ı Sıhhî Heyeti, 1 Ekim 1924 tarihine kadar binlerce Türk mübadilin iskân, iaşe, sağlık ve diğer ihtiyaçlarını karşılayarak onların Türkiye'ye sevklerine katkıda bulunmuştur. 


\section{KAYNAKÇA}

\section{Arşivler}

Kızılay Arşivi (KA)

Süreli Yayınlar

Türkiye Hilâl-i Ahmer Mecmuası (THAM)

TBMM Zabıt Cerideleri

Türk Kızılay'ı 2010-2015 Stratejik Planı

\section{Raporlar / Salnameler}

Osmanlı'dan Cumhuriyete Hilâl-i Ahmer İcraat Raporları (1914-1928), Yay. Haz. Murat Uluğtekin, M. Gül Uluğtekin, Türk Kızılayı Derneği, Ankara 2013.

Besim Ömer, Hanımefendilere Hilâl-i Ahmer'e Dair Konferans, Yay. Haz. İsmail Hacıfettahoğlu, Türkiye Kızılay Derneği Yayınları, Ankara, 2. Baskı, 2009.

Milli Mücadele'de Hilâl-i Ahmer, Türkiye Büyük Millet Meclisi'nin Teşkilinden Sakarya Zaferine Kadar Icraat Raporu 23 Nisan 1920-23 Eylül 1921, Yay. Haz. İsmail Hacıfettahoğlu, Türkiye Kızılay Derneği, Ankara 2009, s. 13

Meray, Seha Lozan Barış Konferansı (Tutanaklar Belgeler), Ankara Üniversitesi Basımevi, cilt.1, Kitap.2, Ankara 1970.

Osmanlı Hilâl-i Ahmer Cemiyeti Salnamesi (1329-1331), Matbaa-i Ahmet İhsan ve Şükerâsı, İstanbul, (t.y).

\section{Kitap ve Makaleler}

Arı, Kemal, Büyük Mübadele (Türkiye'ye Zorunlu Göç), Tarih Vakfı Yurt Yayınları, İstanbul, 2000.

Akgün, Seçil, ULUĞTEKIN Murat, Hilâl-i Ahmer'den Kızılay'a, TDV Yayıncılık, Ankara, 2002.

Bayındır Goularas, Gökçe, "1923 Türk-Yunan Nüfus Mübadelesi ve Günümüzde Mübadil Kimlik ve Kültürlerinin Yaşatılması", Alternatif Politika, 4/2, 2012, s. 129- 146.

Çapa, Mesut, "Kızılay", İslam Ansiklopedisi, cilt:25, 2002, s. 544- 546.

Çapa, Mesut, "Mübadelede Kızılay (Hilâl-i Ahmer) Cemiyetinin Rolü", Sosyal Bilimler Enstitüsü Dergisi, Sayı: 10, Yıl: 2001, s. 29- 60.

Çapa, Mesut, Kızılay (Hilâl-i Ahmer) Cemiyeti (1914-1925), Türk Kızılayı Derneği, 2. Baskı, Ankara, 2010.

Erdal, İbrahim, "Türk Yunan Nüfus Değişiminde Türk Mübadillere Yapılan Yardım Faaliyetleri”, Ankara Üniversitesi Dil ve Tarih-Coğrafya Fakültesi Tarih Araştırmaları Dergisi, C:XXV, Sayı:40, Kasım 2006, s. 204- 214.

Sarı, Mustafa, Izmit'te Hilâl-i Ahmer Cemiyeti (1911-1925), Babıali Kültür Yayıncılı̆̆ı, İstanbul, 2016.

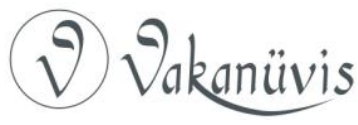


Sarı, Mustafa, “Mübadelede Hilâl-i Ahmer Cemiyetinin Faaliyetleri: Kocaeli Örneği (Ocak-Haziran 1924)", Uluslararası Karamürsel Alp ve Kocaeli Tarihi Sempozyumu II, C. I, Kocaeli Büyükşehir Belediyesi Yayınları, Kocaeli 2016, s. 481- 496.

Sarı, Mustafa, "Milli Mücadele Dönemi'nde İzmit ve Çevresinde Hilâl-i Ahmer Cemiyeti'nin Faaliyetleri (1919-1923)", Uluslararası Gazi Akça Koca ve Kocaeli Tarihi Sempozyumu Bildirileri, C. II, Kocaeli Büyükşehir Belediyesi Yayınları, Kocaeli, 2015, s. 965- 986.

Şenışık, Pınar "1923 Türk-Yunan Nüfus Mübadelesi: Erken Cumhuriyet Döneminde Modern Devlet Pratikleri ve Dönüşen Kimlikler", Studies of The Ottoman Domain, 6/10, Şubat 2016, s. 83- 119. 